\title{
THE DESCRIPTION OF ORGANIZATIONAL COMMITMENT OF REGULAR EMPLOYEE AND FIX-TERM EMPLOYEE: A STUDY ON THE EMPLOYEES OF PT. X NGORO, MOJOKERTO, INDONESIA
}

\author{
Rosli Nur Liftiyah Della, Musadieq Mochammad Al, Aziz Aulia Luqman* \\ Faculty of Administrative Science, University of Brawijaya, Indonesia \\ *E-mail: aulialuqmanaziz@ub.ac.id
}

\begin{abstract}
This study aimed to (1) describe of organizational commitment on regular employee and fixterm employee; (2) describe the role of company in supporting organizational commitment of the employee. The type of research used descriptive research with qualitative approach. The results of the study indicated that regular employees were involved with other activities outside of the main job, felt comfortable and happy to do their current job, and made commitment and felt satisfied if they had to spend their career until retirement, however they wanted higher salary and position, and can work on the appropriate field based on their ability. Fix-term employees indicated that they felt comfortable with the company's environmental conditions, thought positively of wherever they work always feel enjoyed, and had mindset that every job can add knowledge, etc. The company PT. X Ngoro, Mojokerto has been trying to support in increasing employee commitment.
\end{abstract}

\section{KEY WORDS}

Organizational commitment, regular employee, fix-term employee.

One of the considerations for positive change is the company should pay attention to its human resource. According to Mangkuprawira (2003), human resource is the most directly influencing factor toward the company's competitiveness. Human resource is one of important assets to reach the goal of the company that is get maximum profit to assure the long term survival of the company, so human resource management system should be done appropriately to make it the key of the organization's success.

Types of human resource or labor of a company depend on the rule implied in every company. Based on Undang-undang Ketenagakerjaan Republik Indonesia Number 13 Year 2003 , there are two types of labor which are the labor who work in unspecific time (regular) and those who work in a specific time (fix-term). In Indonesia, there are several terms used to call fix-term employee such as contracted employee, freelancer, outsourcing, etc. The difference between regular and fix-term employee is regulated in Labor Act (UU Ketenagakerjaan) Number 13 Year 2003 Paragraph 56 Verse 2 which explains that work agreement for certain period of time (contract) as mentioned in verse 1 is based on (a) certain period of time; (b) deadline of certain work. Based on that explanation, the difference between regular employee and fix-term employee is the work period in a company.

Labor Act Number 13 Year 2003 also set up the working period of fix-term employee as it is mentioned in paragraph 59 verse 1 (b) the work that is estimated to be finished not in a very long time at 3 (three) years maximum. Fix-term employee is also able to extent their working period as mentioned in paragraph 59 verse 4 which explains that working period which is determined on a certain period can be provided for 2 (two) years as the longest and can be extended for maximum 1 (one) time with 1(one) year as the longest. Fix-term employee also has a right to fix over the contract in the company where he works as it is mentioned in paragraph 59 verse 6 which explains that fixing over a contract for certain period can only be provided after 30 (thirty) days over the last day of the contract, and the contract can be fixed over 1 (one) time for maximum 2 (two) years extension.

Different from fix-term employee, although regular employee work for a long period in a company and receives fixed salary but in fact, a survey stated that most of them are still looking for other job outside their main job. According to a survey conducted by one of business-based website, LinkedIn, entitled Talent Trend 2014 on more than 18.000 regular 
employees from 26 countries, 45\% regular employee once doing an interview with other company and another $15 \%$ are making closed-talk with their colleague in other company. The survey also shows that $15 \%$ of regular employees around the world are actively looking for other job outside the company, while other $13 \%$ are looking for other job once a week. It is only $15 \%$ left of the regular employees who feel satisfied with their job and never have any intention to look for other job.

Based on the whole data, Indonesia is a country with a quite high percentage of regular employees who look for other job that is $29 \%$ for the regular employees who are actively look for other job several times a week. The survey also shows that from various countries around the world, Indonesia is included in the highest category for regular employee who shows interest and easily approached and influenced by the outside of the company in term of looking for other job which is $90 \%$.

According to those several statements, both types of employees have their own obstacle which is the short period of time for fix-term employee and the fact from preresearch which shows that regular employee tends to look for other job outside the company. That is why the researcher is interested to discuss the topic about organizational commitment of regular employee and fix-term employee because someone who works in a company must show various attitude and behavior such as interrelation between the employee and the company, the leader, and fellow employees. One of the attitude is the commitment of the employee to the company or well-known as organizational commitment. According to Luthans (2006) someone's attitude that shows his organizational commitment are (1) the willingness to still become member of the organization; (2) the willingness to work hard as required by the organization; and (3) believe in the goal acceptance and organization's value.

By having organizational commitment, an employee is considered certifiable and responsible in doing his task. Regardless to the personnel status, regular or fix-term, when employees have organizational commitment, they will still work hard and do their task as maximum as they can because they care about the company's progression. Organizational commitment is important for an employee because it will make the employee to have more attention toward the success of the company. In other word, the company will receive positive result if the employee implies organizational commitment.

PT. X Ngoro Mojokerto (company's name is disguised) is a company that produces synthetic materials. Its main products are semi-finished raw materials made from PVC or Polyvinyl Chloride such as synthetic skin, tarpaulin, transparent and colored PVC sheets, etc. As a supplier of synthetic material, the company is demanded to develop to fulfill the need of the consumers that keeps increasing. Besides, PVC as a main material is also needed to fulfill people's daily needs. This condition requires the entire member of the company whether the regular employee or the fix-term employee to cooperate and work maximally to apply the strategy that has been determined by the company to compete and to survive in a long period. Besides, the research location is selected with the consideration that it is hard for fix-term employee to be nominated as regular employee and also most of them are from those who already work long enough in the company. Therefore, the researcher is interested to find out how good organizational commitment of the fix-term and regular employee is.

From the previous explanation, the researcher is interested to discuss the topic about organizational commitment on fix-term employee and regular employee to explore deeper about how organizational commitment of fix-term employee whose work period is shorter and the organizational commitment of regular employee which shows that they are looking for other job outside the company. This research is conducted in PT. X Ngoro Mojokerto with the consideration that this company is the only one that produces PVC in Mojokerto and its regular employees are mostly the its old timer employees.

\section{LITERATURE REVIEW}

Regular Employee. Labor law in Indonesia is set in Law manual in which one of them is about regular employee decision. The status of regular employee is bounded by Perjanjian Kerja Waktu Tidak Tertentu (PKWTT). According to Labor Act Number 13 Year 2003 
paragraph 61 about work contract for certain period (regular employee) verse 1 it is mentioned that work contract is over if:

- the employee is passed away;

- the period of the contract is over;

- there is jurisdiction judgment and/or any judgment from department of industrial conflict settlement that has law power;

- there is certain condition that is included in work contract, rules, or cooperation agreement which causes work relation is over.

According to Pacheco, Page and Webber (2004), "Permanent work is generally defined as workers who work all year and have an expectation of continuing employment". On the other side, the definition of regular employee is also stated by Faisal (2009) that regular employee is the employee who receives certain number of fee regularly and periodically. What is included as regular employees are private employee, official servant, and pension fund acceptor. The fee here can be salary, various subsidies, and non-specified income such as bonus, honorarium, production compensation, gratification, and many more.

Fix-term Employee. The definition of fix-tem employee or outsourcing according to Dessler (2015) is the activity of commanding the vendor outside the company to supply someone's service or merit for research, manufacture, etc. which is previously conducted by the company's employee itself. Oz (2009) stated that "Outsourcing in general means hiring the services of another organization or individual to perform some of the work that otherwise would be performed by you or your employees". Outsourcing or fix-term employment in general is leasing other organization's or individual's service to do several works that is not done by the employee of the company itself.

According to Herawati (2010), contract or outsourcing is a work relation that is included as precarious work or international term to depict a situation of unsettled work relation, freelancer, certain period, etc. In Indonesia, the definition of fix-term employee can be seen in Labor Act number 13 year 2003 paragraph 59 verse 1 about work contract for certain period that only possible to be made up for certain work, which is based on its type and character can be finished in certain period, that is:

- the work that can be done at once or temporary work;

- the work that is estimated to be finished not in a very long time, three years maximum;

- seasonal work;

- the work that is related to the trial of new product, activity, or additional product.

In the same paragraph verse 3 added more explanation that work contract for certain period can be extended or be fixed over. Paragraph 59 verse 4 also mentioned the condition for the contract extension, that is for two years maximum and only once in one year maximum. The definition of outsourcing in Indonesia is set in Labor Act paragraph 64 that stated a company can turn over a part of its work to other company through written agreement of work contracting or by providing employees.

Organizational Commitment. Organizational commitment according to Mathis and Jackson (2009) is the level where an employee believes and accepts the goal of the organization and also sure enough to stay in the organization. Griffin (2005) explained about the definition of organizational commitment as an attitude that depicts how far an individual knows and relates the organization he joins in. According to Robbins (2003), the definition of organizational commitment is a condition where an employee chooses to lean on certain organization and its purposes and intended to maintain his membership.

Steers and Porter (in Sopiah, 2008) stated that the occurring commitment is not just passive loyalty but also involving active relationship with the organization in form of work which is aimed to give the best effort to succeed the organization. Agree with that statement, Mowday (in Sopiah, 2008) stated that organizational commitment is an important behavior dimension that can be used to assess an employee's tendency to stay as a member of the organization. 
There are three models of organizational commitment proposed by Meyer and Allen (in Luthans, 2006) as follows:

- Affective commitment is a commitment that is related with employee's emotional attachment, identification, and involvement in the organization.

- Continuance commitment is a commitment based on the loss that is related to the employee's leaving the organization. It is possibly because of losing seniority on promotion or benefit.

- Normative commitment is the feeling of having obligation to stay in the organization; that action is the right one to do.

Smith (in Sopiah, 2008) also mentioned three forms of organizational commitment in a company, they are:

- Affective commitment that is employee's emotional attachment, identification and involvement of an employee is an organization. An individual stands to stay in an organization because of emotional attachment and based on their willingness.

- Continuance commitment is a commitment based on the loss that is related to the employee's leaving the organization. An employee stands to stay in an organization because he needs benefit or salary which cannot be given by another job.

- Normative commitment is the feeling of having obligation to stay in the organization and because that action is the right one to do. An employee chooses to stay in an organization because of the feeling that they have to be loyal to the organization and to be appropriate with that value of the organization.

\section{METHODS OF RESEARCH}

This research is a descriptive research using qualitative approach. This research was conducted in PT. X located in Ngoro Industrial Area, Candiharjo Village, Ngoro, Mojokerto, East Java, Indonesia. The object of this research was a manufacturing company which produces semi-finished materials from synthetic raw material (Polyvinyl Chloride/PVC) in form of synthetic skin, tarpaulin, transparent PVC sheet, colored PVC sheet, etc. Data collection techniques used by the researcher were: interview, documentation, supporting tools, and the researcher. The focuses of this research were:

- An Outlook of Regular Employee's Organizational Commitment of PT. X Ngoro, Mojokerto;

- An Outlook of Fix-Term Employee's Organizational Commitment of PT. X Ngoro, Mojokerto;

- The Role of The Company To Support Regular Employee's and Fix-Term Employee's Organizational Commitment of PT. X Ngoro, Mojokerto.

\section{RESULTS AND DISCUSSION}

\section{Mojokerto: \\ An Outlook of Regular Employee's Organizational Commitment of PT. X Ngoro, \\ Affective Organizational Commitment. Affective organizational commitment has big} influence for both the company and the employee if each employee has that attitude. One of the characteristics of the employee with affective organizational commitment is the feeling that there is strong emotional attachment between the company and the employee himself that stimulates him to do any activity related to the company voluntarily, with no expectation for fee, doing his work wishfully, and has willingness to stay in the company.

The research result depicts organizational commitment of regular employee of PT. $X$ Ngoro, Mojokerto that is showed by the willingness to stay and work to spend the rest of career life in the company until they are retired. The employees admit that this decision is made as it flows. They feel satisfied with their recent condition, position, work field and the salary they receive. Therefore, the work they are doing today is considered as bliss they have to enjoy and it is something pleasing because the knowledge they got can be used for 
learning, insight, and experience so later they will be able to enjoy wherever and whatever they are working. Another reason for them to stay in the company beside the salary is the pleasure they feel when they are learning the field they never know before. Several sections of the company have an obligation to be creative and innovative for the product. This is one of the reasons the employee will never feel bored while working so working becomes something interesting to do.

As long as they are working in the company, they admit that they care about the company. The employees feel that the company is theirs. The company belongs to all the employees working over there. That thought is implanted in order to make them remember that what they get, in this case is salary and other subsidy for their living comes from the company. Regular employees say they want to break the thought "if only by loafing they can get their salary, why should I work hard to develop this company". Although this condition looks simple but the act to avoid that behavior naturally appears from deep inside the employee's heart so they always remind themselves, even their colleague to keep working well for the development of the company.

This description agrees with Smith (in Sopiah, 2008) who stated that "affective commitment is employee's emotional attachment, identification, and involvement in the organization. People choose to stay in an organization because of their emotional attachment and based on their own willingness". Thus it can be depicted that regular employees of PT. X Ngoro, Mojokerto have affective organizational commitment toward the company which occurs naturally, the employee's feeling toward the company occurs because there is emotional attachment without being influenced by anyone, such as positive thought while working. The employee always takes good side for any placement, for example, they will get new experience. Besides, there is satisfaction for what they already achieved and do not need to push themselves to reach certain position so they will be retired happily. This is an example of affective organizational commitment.

Continuance Organizational Commitment. The research result shows that regular employees of PT. X Ngoro, Mojokerto have ever tried to look for another job outside the company. It is because they want to apply their knowledge. Their recent job is considered inappropriate with their basic skill. Besides, the desire to develop the talent and knowledge they already had also motivates them to try working on another field. Higher position and better salary also influence them to work in other company. One of the employees even states that he will accept work offer from state-owned corporation although he will get the same amount of salary. It is because this employees desires to work in state-owned company.

This description does not meet the statement by Smith (in Sopiah, 2008) that continuance commitment is a commitment based on the loss that is related to the employee's leaving the organization. Therefore it can be depicted that interviewee has tried to look for another job because they want to get higher position. Better salary and higher position is also considered with the reason that recent job does not meet their basic skill and they wish to get work which is appropriate with their skill and offer better salary.

Normative Organizational Commitment. The result of the research shows that regular employees of PT. X Ngoro, Mojokerto make various efforts to stay in the company like working to reach the target also maintaining communication with the company to avoid misunderstanding while they are working. That effort is made because the employees care about the development of the company. This sense of caring occurs as the result of the feeling that the company is the place to look for a living, the result of their work is used to support their family. That is why the employee stays in the company for years. The employee also thinks and works hard to make the company survive for a long time. Besides, regular employees of PT. X Ngoro, Mojokerto agree that the company is worth their loyalty because the company has well fulfilled their rights as an employee by providing them with salary and subsidy.

These conditions agree with the statement by Smith (in Sopiah, 2008) that normative commitment is the feeling of having obligation to stay in the organization and because that action is the right one to do. An employee chooses to stay in an organization because of the 
feeling that they have to be loyal to the organization and to be appropriate with that value of the organization. That is why it can be depicted that regular employees of PT. X Ngoro, Mojokerto has normative organizational commitment which is proven by their efforts to stay in the company. Having the sense of caring toward the company by thinking about how the company can be developed and give their loyalty to the company because the company has given what they need.

\section{Mojokerto:}

An Outlook of Fix-Term Employee's Organizational Commitment of PT. X Ngoro,

Affective Organizational Commitment. Based on the result of the interview it is found that fix-term employees of PT. X Ngoro, Mojokerto feel happy and comfortable working on their recent job. It is because the company environment is enjoyable with the people who are easily communicate and work together with each other that makes them feel comfortable. Although those fix-term employees do not have any working experience before, they still feel happy to work in this company. That is because the employees think that experience and knowledge are important to be explored during they work. Therefore, the employees feel that wherever they work they have to enjoy because it is such a journey to be success. Although level of career is important, they feel satisfied because fix-term employees are never underestimated. The employees also regard that the company appreciate their work not only in form of salary and subsidy but compliment is also important for them. So the employees always try to be loyal to the company as long as the company appreciates their work.

This description agrees with Smith (in Sopiah, 2008) who stated that "affective commitment that is employee's emotional attachment, identification, and involvement in the organization. People choose to stay in an organization because of their emotional attachment and based on their own willingness". It can be depicted by the willingness of the employee to stay in the company because of the environment and the people around them are comfortable and easily communicate to each other. The thought that wherever they work is a part of a journey to get more experience and knowledge is a positive thought of the employee that motivated them to work seriously although they are only working for several years.

Continuance Organizational Commitment. The result of the research shows that fixterm employees of PT. X Ngoro, Mojokerto feel comfortable and do not need to look for other job because there are lots of considerations for them to look for other job such as old age factor so they choose to work maximally. The hope that the company trusts their performance and they will be called to work again later rather than looking for a new job which they cannot guarantee they are able to effort. Beside the salary, adapting new environment, new people, and learning new work field from the very beginning are difficult for them that make them prefer to stay in the company. Although working in other company will upgrade their experience and knowledge, fix-term employee thinks there is always possibility that they will be moving to another division so their knowledge will be still upgraded. It makes them think there is no need to out and looking for a new job. It is better for them to develop their performance because comfortable work environment and partners are difficult to leave.

This description does not meet the statement by Smith (in Sopiah, 2008) that continuance commitment is a commitment based on the loss that is related to the employee's leaving the organization. An employee stands to stay in an organization because he needs benefit or salary which cannot be given by another job. It is proven by the positive attitude shown by the employee. They believe that the company will give them good level of career if they work maximally. The company will also consider their contract if the employees' performance keeps better. The employees also think that the pleasure they maintain during their work can be found in other company. That is why the employees choose to stay.

Normative Organizational Commitment. The result of the interview shows that fix-term employee of PT. X Ngoro, Mojokerto makes efforts to stay in the company like working maximally as commanded by the management and do their task as good as they can to be trusted by the company. It is done by the employee as their concern to the company. Fixterm employees admit that although their effort is not much and influencing enough, but if all the employees are care about the company the result will be good. Like making outcome 
efficiency, trying to routinely come to work and working maximally. The employees argue that there will be no employee that wants the company to be broken because if it is happen they will also be broken. They state so because they regard working on the target is an obligation. So the employees' performance is also a proof of their desire to be trusted by the company. When a fix-term employee does not work maximally and seriously, it is considered as sign that the employee does not want to get trusted and does not want to stay in the company.

These conditions agree with the statement by Smith (in Sopiah, 2008) that normative commitment is the feeling of having obligation to stay in the organization and because that action is the right one to do. An employee chooses to stay in an organization because of the feeling that they have to be loyal to the organization and to be appropriate with that value of the organization. That is why it can be depicted that fix-term employee of PT. X Ngoro, Mojokerto has normative organizational commitment proven by the effort to stay in the company, a form of concern that is shown by doing their job maximally and also the employee's loyalty because the company appreciates their work.

The Role of The Company to Support Regular Employee's and Fix-Term Employee's Organizational Commitment of PT. X Ngoro, Mojokerto.

Communication Tangle Built by the Company to Regular Employee and Fix-Term Employee. A good communication tangle between a company and its employee affects the employee's assessment toward their workplace. The employee will feel comfortable and appreciated if the communication is goes smoothly. It of course refers to the commitment of the employee. Is the employee feels appreciated because of the communication with the company is comfortable it will help to build organizational commitment of the employee. The employee who has organizational commitment will give good impact to the company.

From the result of interview it is found that the company has built a good communication tangle with its employees. The company always shares information with the same way that is respectful and regardless to the status of the employee. Although the employees have the same position with different status, the company still gathers all of them in the same room so there is no difference among individual. It is also supported by the result of researcher's observation about the statement that the leader, in this case is the manager, always communicates well with the employees, for example in direct monitoring or just chit chat whether using mobile phone or direct talk. This description agrees with the statement by Dessler (in Luthan, 2006) who gave manuals about how to solve problem that can help to increase organizational commitment of the employee, which is "Committed to main value of human being. Make written rules, employ good and appropriate manager, and maintain communication".

Support of the Company toward the Employee's Development. The employees' development is important to be given by the company to support their skill, such by giving promotions, giving challenging work, and giving chance for the employee to actualize themselves. Those matters will make the employee feel that their future is considered by the company, besides they are sure enough to stay in the company if their level of career is secured. Organizational commitment will appear if the employee feels safe working in the company.

Based on the result of interview, it is found that PT. X Ngoro, Mojokerto has supported its employee's development by giving promotion to each employee. The promotion is giving regardless to the status of the employee whether they are regular or fix-term employee. The promotion is given based on their achievement. Besides, the company also gives instruction and training for the new employees and for those whom division is changed by the leader. It is beneficial for the employees' introducing and comprehending toward their work field. This description agrees with the statement by Dessler (in Luthan, 2006) who gave manuals about how to solve problem that can help to increase organizational commitment of the employee, which is "Supporting employee's development. Doing actualization; giving challenging job in their first year; push forward and empowering; promotion from within; providing developing activity; proving bail-free security for the employee".

Form of Justice of the Company toward Its Regular and Fix-Term Employees. From the result of interview it is found that PT. X Ngoro, Mojokerto has tried to do justice toward each 
employee regardless to their status. It is proven by rewarding the employee with the same nominal if they can reach the target. It is also applied in punishment giving whenever the employee breaks the rule that is by calling the employee and warn him. It is all applied similarly for all regular or fix-term employees. This description agrees with the statement by Dessler (in Luthan, 2006) who gave manuals about how to solve problem that can help to increase organizational commitment of the employee, which is "Assuring organizational justice. Having comprehensive procedure for complaint submission; and providing extensive two-ways communication".

Facility Provided to Support the Employees' Activity. The result of interview shows that PT. X Ngoro, Mojokerto has afforded to provide facilities to support its employees' activity. The facilities are employee bus and providing scholarship for the employees' children with good achievement. Besides, the company has also built a new building to support the employees' performance which is aquipped with better facilities. This description agrees with the statement by Dessler (in Luthan, 2006) who gave manuals about how to solve problem that can help to increase organizational commitment of the employee, which is "Supporting employee's development. Doing actualization; giving challenging job in their first year; push forward and empowering; promotion from within; providing developing activity; proving bailfree security for the employee".

\section{CONCLUSION}

According to the result of this research, in can be concluded that:

Based on result of interview, it is found that regular employees of PT. X Ngoro, Mojokerto imply affective and normative organizational commitment well which is shown by (1) involving in other activity outside their main job, (2) feeling comfortable and happy in their recent job, (3) having commitment and feeling satisfied if they have to spend their rest career until retired, (4) always put their best effort to stay in the company, (5) care about the company's development because the company always fulfills and appreciates the employees appropriately.

There is inexpediency between the attitudes of regular employees of PT. X Ngoro Mojokerto with continuance organizational commitment. The employees admit that they have tried to look for other job during their career in the company for following reasons: (1) wishing for better salary, (2) wishing for higher position, (3) wishing to work in the field that is appropriate with their basic skill.

Fix-term employees of PT. X Ngoro Mojokerto have affective, continuance, and normative organizational commitment. It is depicted in their attitude such as (1) feeling comfortable with the company environment, (2) think positively that any workplace should be enjoyed, (3) having mindset that any job can upgrade their knowledge, (4) work maximally, (5) loyal and care about the company because they are appreciated as they wish such as subsidy, compensation, and compliment.

PT. X Ngoro, Mojokerto has put its best effort to support the employees' commitment increasing by treating its employee similarly regardless to their employment status. The company tries to be equal in building communication and sharing information. The company also provides career level opportunity for each employee and being equal in giving reward and punishment. Facility fulfillment is also provided to support the employee's activity such new building, employee's bus, and scholarship for the employees' children.

According to research result there are several suggestions for the company's improvement as follows:

The research result shows that several employees state inexpediency with continuance commitment so the researcher suggests for organizational commitment to be more emphasized especially the continuance aspect.

The employees who represent appropriate attitude with organizational commitment are expected to keep and improve the commitment because it will be beneficial for the company and the employees themselves. 
According to the research result with the company in its role to improve employee's commitment has been appropriate and has put its best effort to support the employees. Meanwhile, based on the observation result the researcher's suggestion for the company is to pay attention to the facility that needs maintenance not only adding more facilities without taking care about its treatment which makes them broken and uncomfortable to be used. In this case the road to the company which is broken, the company needs to fix it.

\section{REFERENCES}

1. Dessler, G. (2009). Manajemen Sumber Daya Manusia. Jakarta: Indeks.

2. (2015). Manajemen Sumber Daya Manusia. Jakarta: Salemba Empat.

3. Faisal, G. (2009). How to be Smarter Tax Payer. Jakarta: Grasindo.

4. Griffin, W. R. (2004). Manajemen (7th Ed). Jakarta: Erlangga.

5. (2005). Manajemen. Jakarta: Erlangga.

6. Herawati, R. (2010). Kontrak dan Outsourcing Harus Makin Diwaspadai. Bandung : Akatiga Pusat Analisis Sosial.

7. Linkedin. (2014). Talend Trend 2014: What'on the minds of the professional workforce. Retrieved from https://business.linkedin.com/

8. Luthans, F. (2006). Perilaku Organisasi, Edisi Sepuluh. Yogyakarta: ANDI.

9. Mangkuprawira, T. S. (2003). Manajemen Sumber Daya Manusia Stretejik. Jakarta: Ghalia Indonesia.

10. Mathis, R. L., \& Jackson, J. H. (2009). Manajemen Sumber Daya Manusia. Jakarta: Salemba Empat.

11. Oz, E. (2009). Management Information System. USA: Thomson Course Technology.

12. Pacheco, G., Page, D. \& Webber, D. J. 2004. Temporary Versus Permanent Employment: Does Health Matter? Australian Journal of Labour Economics, 18(2): 169186. Available from: http://eprints.uwe.ac.uk/25465.

13. Robbins, P. S. (2003). Perilaku Organisasi. Tranlasted by Tim Index. Jakarta: Salemba Empat.

14. Sopiahs. (2008). Perilaku Organisasi. Yogyakarta: Andi. 